\title{
Reproductive biology and embryonic development of Squalus blainvillei in the eastern Mediterranean Sea
}

\author{
VASILIKI KOUSTENI and PERSEFONI MEGALOFONOU \\ Department of Biology, Section of Zoology-Marine Biology, University of Athens. Panepistimiopolis, Ilisia, \\ 15784, Athens, Greece. E-mail: pmegalo@biol.uoa.gr
}

SUMMARY: A total number of 526 Squalus blainvillei was sampled from the bottom trawl and bottom longline catches in the eastern Mediterranean Sea from December 2004 to December 2009. Females outnumbered males and the overall sex ratio was 1.26:1. Females ranged from 182 to $779 \mathrm{~mm}$ in total length and males from 180 to $799 \mathrm{~mm}$. Both females and males showed allometric growth (b>3) and we found statistically significant differences in the relationship between length and weight. Out of the specimens examined, $36 \%$ of females and $63 \%$ of males were sexually mature. Males reached sexual maturity at smaller sizes than females. The smallest sexually mature female was $523 \mathrm{~mm}$ in total length, while the smallest sexually mature male was $425 \mathrm{~mm}$ in total length. Mean length at 50\% maturity was estimated at $564.4 \mathrm{~mm}$ for females and $457.7 \mathrm{~mm}$ for males. Sexually mature specimens of both sexes with mature gonads and high GSI were present in high proportions in every season of the year, which indicates a continuous reproductive cycle. Ovarian oocytes continued to develop throughout gestation. Females carrying near-term embryos had large, equally developed ovarian oocytes, which suggests that they ovulate soon after parturition. Ovarian fecundity ranged from 1 to 7 and uterine fecundity ranged from 1 to 6 . Embryo length and yolk sac weight were negatively correlated.

Keywords: Squalus blainvillei, maturity, fecundity, embryonic development.

\begin{abstract}
RESUMEN: Biología REPRODUCTIVA y DESARRollo EMBrionARIO DE SQUALUS BLAINVILLEI EN EL ESTE DEL MAR MEDITERRÁNEO. - Un total de 526 Squalus blainvillei procedentes de pescas de arrastre de fondo y palangres de fondo se muestrearon en el este del Mar Mediterráneo, desde diciembre de 2004 hasta diciembre de 2009. Las hembras excedieron en número a los machos y el cociente de sexos fue 1.26:1. Las hembras midieron entre 182 y 779 mm de longitud total y los machos de 180 a $799 \mathrm{~mm}$. Tanto machos como hembras mostraron un crecimiento alométrico (b>3), pero se encontraron diferencias estadísticamente significativas en la relación talla y peso. De los especímenes examinados, el 36\% de las hembras y el 63\% de los machos eran sexualmente maduros. Los machos alcanzaron la madurez sexual a tamaños más pequeños que las hembras. La hembra sexualmente madura de menor talla tenía una longitud total de $523 \mathrm{~mm}$, mientras que el macho sexualmente maduro más pequeño tenía una longitud total de $425 \mathrm{~mm}$. La talla media al $50 \%$ de madurez, se estimó en $564.4 \mathrm{~mm}$ para las hembras y en $457.7 \mathrm{~mm}$ para los machos. Los especímenes de ambos sexos sexualmente maduros, con gónadas maduras y alto GSI estuvieron presentes en elevadas proporciones en todas las estaciones del año, indicando un ciclo reproductivo continuo. Los oocitos ováricos continuaron desarrollándose durante la gestación. Las hembras que llevaban embriones desarrollados tenían grandes oocitos ováricos igualmente desarrollados, lo que hace pensar que ovulan pronto después del parto. La fecundidad ovárica varió de 1 a 7 y la fecundidad uterina de 1 a 6 . La longitud de los embriones y el peso del saco vitelino estuvieron correlacionados negativamente.
\end{abstract}

Palabras clave: Squalus blainvillei, madurez, fecundidad, desarrollo embrionario.

\section{INTRODUCTION}

The longnose spiny dogfish Squalus blainvillei (Risso, 1826) is an aplacental viviparous benthic shark belonging to the Squalidae family. It occurs in tropical and temperate waters and inhabits depths to about 700 $m$ in the Atlantic, Pacific, and Indian Oceans, including the Mediterranean and Black Seas (Compagno et al., 2005; Serena, 2005). Compared to other shark species, there are very few studies on longnose spiny dogfish in the Mediterranean basin and knowledge of the biology, distribution, and exploitation of this species is 
still very poor. Some specific but preliminary studies on age, growth and maturity have been carried out in the western-central Mediterranean (Ledoux, 1970; Cannizaro et al., 1995; Massutí and Moranta, 2003). In the eastern Mediterranean, stomach contents of the species from the north Aegean Sea have been analyzed (Kabasakal, 2002), while there is little knowledge on its reproductive biology and distribution in the Ionian Sea (Sion et al., 2003).

Currently there is growing concern over the extent of shark catches in the Mediterranean, as their Kselected life-history characteristics make them intrinsically vulnerable to fishing pressure (Dulvy et al., 2008). The available evidence indicates that sharks in the Mediterranean Sea are generally declining in abundance, and are possibly facing a worse scenario than shark populations elsewhere in the word. This decline can be attributed to a number of factors, including their life history characteristics in combination with the semi-closed nature of the Mediterranean Sea and intense fishing activity. In Greece and other Mediterranean countries, the longnose spiny dogfish is a commercial species that is obtained from incidental catches of bottom trawl and long line vessels; however, there are no official records of its landings and limited information on its population characteristics. Attempts to manage longnose spiny dogfish resources will require, among other demographic data, information on its reproductive parameters. For the above reasons, the aim of the present study is to provide new information on the reproductive strategy of the longnose spiny dogfish in the eastern Mediterranean Sea along with important reproductive parameters of its life history traits. This study focuses on the minimum size at first maturity, mean total length at $50 \%$ maturity, fecundity, litter size, embryonic development, and reproductive cycle. Two biological indices, the gonadosomatic index (GSI) and hepatosomatic index (HSI), were examined to test how they change during the year and the reproductive cycle.

\section{MATERIALS AND METHODS}

\section{Sampling and measurements}

A total number of 526 longnose spiny dogfish was obtained from the bottom trawl and bottom longline catches in the eastern Mediterranean Sea from December 2004 to December 2009. The bottom trawl hauls were carried out in depths between 125 and $475 \mathrm{~m}$ in the Aegean Sea, while the longline sets were in depths between 350 and $480 \mathrm{~m}$ in the Levantine Basin (Fig. 1). All specimens were initially preserved in ice (on board) and later frozen at $-20^{\circ} \mathrm{C}$ until dissection. Specimens were processed at the laboratory after thawing. The identification was confirmed and measurements were taken based on Compagno (1984). The total length (TL) of each specimen was measured to the nearest millimetre $(\mathrm{mm})$, from the tip of the snout to the tip of

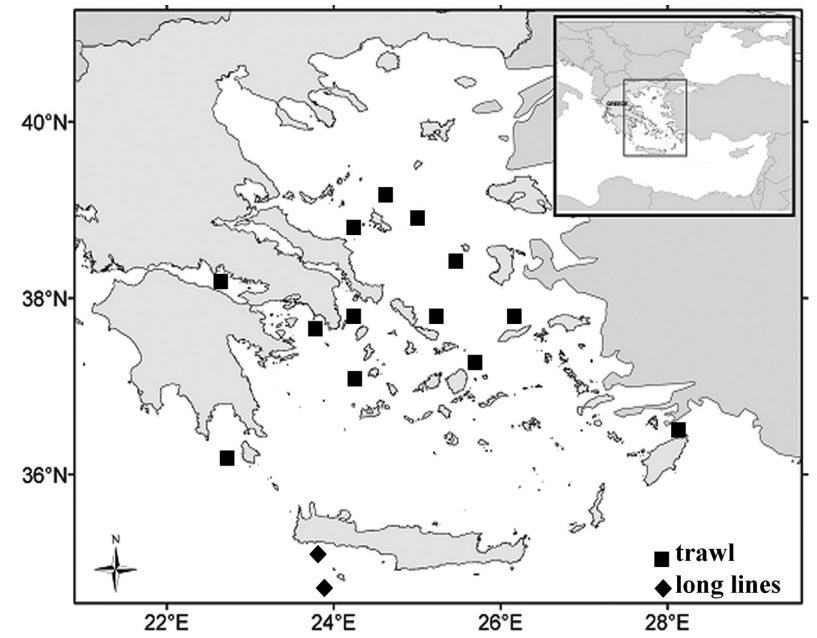

FIG. 1. - Map of the study area in the eastern Mediterranean Sea illustrating the sampling sites at which Squalus blainvillei specimens were caught by bottom trawl and bottom long lines from 2004 to 2009.

the upper lobe of the caudal fin. Round weight (RW) was measured as the total weight of the specimens, and eviscerated weight (EW) was measured after the organs had been removed from the body cavity. All weight measurements were taken using electronic balances to the nearest gram $(\mathrm{g})$. Total length frequency distributions were analyzed separately for each sex while regression analysis was used to determine length-weight relationships $\left(\mathrm{Y}=\mathrm{aX}{ }^{\mathrm{b}}, \mathrm{Y}=\right.$ round weight, $\mathrm{X}=$ total length). The Kolmogorov-Smirnov two-sample test was used to test for significant differences in the length frequencies by sex. The slopes of the regressions were tested against the isometric slope standard of 3 with the Student's t-test.

The length and weight of the liver and reproductive organs were measured in order to examine changes in these structures during the maturation process. For males, inner length (CLI), outer length (CLO) and base width (CLB) of the left clasper and length, width and weight of both left and right testes were recorded. CLI was measured from the point of insertion at the cloaca to the distal tip of the clasper and CLO was measured from the point of outside insertion at the pelvic fin to the tip of the clasper (Compagno 1984). For females, the length, width and weight of the ovaries and oviducts were measured. Liver and reproductive organs were measured to the nearest $0.1 \mathrm{~mm}$ using Vernier calipers and were weighed to the nearest $0.1 \mathrm{~g}$ using an electronic balance. The mean and standard deviation were calculated only if the sample size was greater than two. Regression analysis was used to describe relationships between gonad weight (GW) and total length (TL), and left uterus width (UW) and total length (TL) in females. In males, regression analysis was used to describe relationships between gonad weight (GW) and total length (TL), and left clasper inner length (CLI) and total length (TL). 
TABle 1. - Sexual maturity scale used to describe the maturity stages of male Squalus blainvillei.

\begin{tabular}{|c|c|c|}
\hline \multicolumn{2}{|c|}{ Stage } & \multirow{2}{*}{$\begin{array}{l}\text { Description } \\
\text { Claspers soft and small, not exceeding } \\
\text { the pelvic fins; testes thread-like and } \\
\text { undeveloped; sperm ducts undeveloped. }\end{array}$} \\
\hline I. & Immature & \\
\hline II. & Maturing & $\begin{array}{l}\text { Testes enlarged; claspers soft and small not } \\
\text { exceeding the pelvic fins; sperm ducts } \\
\text { beginning to coil. }\end{array}$ \\
\hline III. & Mature & $\begin{array}{l}\text { Claspers rigid, longer than the pelvic fins; } \\
\text { testes enlarged; sperm ducts extremely } \\
\text { coiled at proximal end of ducts. }\end{array}$ \\
\hline IV. & Adult-running & $\begin{array}{l}\text { Claspers rigid and longer than the pelvic } \\
\text { fins; enlarged testes; sperm ducts } \\
\text { extremely coiled with sperm present } \\
\text { throughout their length; sperm flows with } \\
\text { pressure on the cloaca. }\end{array}$ \\
\hline
\end{tabular}

\section{Sex ratio}

Sex was determined by direct examination for the presence/absence of the claspers. The sex ratio (females:males) was calculated for the total number of specimens and for each season. Moreover, sex ratio was calculated by size. The chi-squared test (Zar, 1996) was used to examine the differences between observed sex ratios and the expected ratio of an equal 1:1 proportion.

\section{Sexual maturity assessment}

Sexual maturity was assessed by macroscopic observation of the reproductive organs according to Stehmann (1987). Males were assessed according to the length and rigidity of the claspers, the size and condition of the testes and sperm sacs, the coiling of the sperm ducts and the presence of sperm in the genital tract. For males, a four-stage maturity scale was used (Table 1). For females, sexual maturity was determined from the size and colour of the ovarian ova and the state of the uteri (Stehmann, 1987). After classifying females into ovarian and uterine maturity stages a seven-stage sexual maturity scale was established (Table 2 ). For both sexes, only fish in stage III or above were considered mature. The distribution of maturity stages for females and males was analyzed according to size, and the minimum size at first maturity was determined. The reproductive cycle of the species was studied by analyzing the seasonal evolution of the maturity stages as percentages by sex.

Length at $50 \%$ maturity was determined by fitting maturity ogives. The percentages of mature individuals per length class $(10 \mathrm{~mm})$ were estimated for males and females separately. A logistic curve was fitted to the data and the total length at which 50\% of individuals are sexually mature was calculated (King, 1995) using the equation: $\mathrm{P}_{\mathrm{i}}=1 /\left[1+\mathrm{e}^{(\mathrm{a}+\mathrm{bL})}\right]$, where $\mathrm{P}_{\mathrm{i}}$ is the proportion of mature individuals in length class $i$ and $a$ and $b$ are fitted parameters which can change during the life cycle. The mean length at sexual maturity was calculated as $L_{50}=a / b$ (Spare and Venema, 1992).
TABLE 2. - Sexual maturity scale used to describe the maturity stages of female Squalus blainvillei.

\begin{tabular}{|c|c|c|}
\hline Stag & & Description \\
\hline I. & Immature & $\begin{array}{l}\text { Non-gravid females with thin, thread-like } \\
\text { uteri and immature ovaries. Small, white- } \\
\text { transparent ovarian oocytes with diameter } \\
\text { less than } 1 \mathrm{~mm} \text {. }\end{array}$ \\
\hline II. & Developing & $\begin{array}{l}\text { Non-gravid females with thin, thread-like or } \\
\text { expanded-developing uteri and developing } \\
\text { ovaries. White and yellowish oocytes with } \\
\text { diameter reaching } 20 \mathrm{~mm} \text {. }\end{array}$ \\
\hline III. & $\begin{array}{l}\text { Mature, } \\
\text { ripe ova }\end{array}$ & $\begin{array}{l}\text { Non-gravid females with thin, thread-like or } \\
\text { expanded-developing uteri and mature } \\
\text { ovaries with a few large, yellow in colour, } \\
\text { ovarian oocytes (diameter over } 20 \mathrm{~mm} \text { ) } \\
\text { along with smaller maturing white-yellow } \\
\text { oocytes. }\end{array}$ \\
\hline IV. & Post-ovulatory & $\begin{array}{l}\text { Post-ovulatory females with expanded and } \\
\text { rounded uteri full of yolk Ovary usually } \\
\text { with small immature and maturing white- } \\
\text { yellow oocytes with diameter reaching } \\
20 \mathrm{~mm} \text {. }\end{array}$ \\
\hline V. & $\begin{array}{l}\text { Gravid, } \\
\text { yolk balls }\end{array}$ & $\begin{array}{l}\text { Gravid females with uteri containing large } \\
\text { differentiated yolk balls that can be counted } \\
\text { and weighed. Ovary usually with small im } \\
\text { mature and maturing white-yellow oocytes } \\
\text { with diameter reaching } 20 \text { mm. A few } \\
\text { larger ripe oocytes may be present. }\end{array}$ \\
\hline VI. & $\begin{array}{l}\text { Gravid, } \\
\text { developing } \\
\text { embryos }\end{array}$ & $\begin{array}{l}\text { Gravid females with developing embryos } \\
\text { bearing external yolk sac. Ovaries usually } \\
\text { with a few large, ripe yellow oocytes } \\
\text { (diameter over } 20 \mathrm{~mm} \text { ) along with smaller } \\
\text { immature and maturing white-yellow } \\
\text { oocytes. }\end{array}$ \\
\hline VII. & Post-natal & $\begin{array}{l}\text { Post-natal females with empty flaccid uteri. } \\
\text { Ovaries with a few large, ripe yellow } \\
\text { oocytes (diameter over } 20 \mathrm{~mm} \text { ) along with } \\
\text { smaller immature and maturing white- } \\
\text { yellow oocytes. }\end{array}$ \\
\hline
\end{tabular}

\section{Gonadosomatic and hepatosomatic indices}

The gonadosomatic (GSI) index was calculated using the following equation $\mathrm{GSI}=(\mathrm{GW} / \mathrm{EW}) \times 100$, where GW is gonad weight in $\mathrm{g}$ and $\mathrm{EW}$ is eviscerated weight of the specimens in $\mathrm{g}$. The hepatosomatic (HSI) index was calculated using the following equation: $\mathrm{HSI}=(\mathrm{LW} / \mathrm{EW}) \times 100$, where LW is liver weight in $\mathrm{g}$ and EW is eviscerated weight of the specimens in $\mathrm{g}$. Variations in GSI and HSI related to sexual maturity stage and season were examined in both sexes. Analysis of variance (ANOVA) was used to test for significant differences in mean GSI values and in mean HSI values between females and males as well as among seasons.

\section{Fecundity}

Fecundity assessments were conducted for mature female sharks. Ovarian fecundity was estimated by the number of ripe oocytes (yellow colour, yolky) in the ovaries of mature females. The diameters and weights of ripe oocytes were measured and recorded separately for each ovary. In addition, the diameters and weights of randomly chosen oocytes, smaller in size, were 
TABLE 3. - Sample size by sex and season and summary statistics for total length (TL) and round weight (RW) of Squalus blainvillei caught in the eastern Mediterranean Sea from 2004 to 2009. N, number; SD, standard deviation.

\begin{tabular}{|c|c|c|c|c|c|c|c|c|c|}
\hline \multirow[t]{2}{*}{ Season } & \multirow[t]{2}{*}{ Sex } & \multirow[t]{2}{*}{$\mathrm{N}$} & \multicolumn{3}{|c|}{ TL (mm) } & \multirow[t]{2}{*}{$\mathrm{N}$} & \multicolumn{3}{|c|}{ RW (g) } \\
\hline & & & Range & Mean & SD & & Range & Mean & SD \\
\hline \multirow[t]{3}{*}{ Spring } & & 81 & $390-738$ & 532.0 & 95.6 & 81 & $240-2550$ & 873.3 & 549.9 \\
\hline & & 72 & 405-799 & 495.2 & 58.5 & 72 & $300-3079$ & 589.0 & 335.0 \\
\hline & 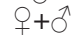 & 153 & $390-799$ & 514.7 & 82.1 & 153 & $240-3079$ & 739.5 & 481.5 \\
\hline \multirow{3}{*}{ Summer } & & 52 & $351-629$ & 484.8 & 89.0 & 52 & $204-1700$ & 657.7 & 414.6 \\
\hline & & 35 & $335-555$ & 438.7 & 68.2 & 35 & $112-804$ & 415.7 & 200.2 \\
\hline & $q+0$ & 87 & $335-629$ & 466.2 & 84.0 & 87 & $112-1700$ & 560.3 & 363.4 \\
\hline \multirow[t]{3}{*}{ Autumn } & & 120 & $321-779$ & 532.1 & 103.4 & 110 & $192-2900$ & 910.4 & 542.1 \\
\hline & 0 & 94 & $272-589$ & 475.8 & 66.6 & 83 & $90-993$ & 570.2 & 203.4 \\
\hline & $q+c$ & 214 & $272-779$ & 507.4 & 93.3 & 193 & $90-2900$ & 764.1 & 461.5 \\
\hline \multirow[t]{3}{*}{ Winter } & ot & 39 & $182-671$ & 359.0 & 178.3 & 39 & $22-1764$ & 426.5 & 532.9 \\
\hline & $\pi$ & 31 & $180-559$ & 373.4 & 143.4 & 31 & $21-877$ & 322.2 & 272.4 \\
\hline & $++\phi^{\lambda}$ & 70 & $180-671$ & 365.3 & 162.8 & 70 & 21-1764 & 380.3 & 437.5 \\
\hline \multirow[t]{3}{*}{ Total } & 0 & 292 & $182-779$ & 500.5 & 125.9 & 282 & $22-2900$ & 786.2 & 546.7 \\
\hline & o & 232 & $180-799$ & 462.5 & 88.0 & 221 & 21-3079 & 517.1 & 278.8 \\
\hline & $\phi+0^{\lambda}$ & 524 & $180-799$ & 483.7 & 112.2 & 503 & 21-3079 & 668.0 & 468.2 \\
\hline
\end{tabular}

measured. Statistically significant differences in mean diameter and mean weight of ripe oocytes between the right and left ovaries were examined. Regression analysis was used to describe the diameter-weight relationships of maturing and ripe oocytes and a diagram of the oocyte diameter frequency distribution was made. Uterine fecundity was determined from the number of embryos occupying the uteri and we examined whether female total length is highly correlated with the number of embryos in their uteri. Data collected on litters included the number of embryos, maternal length, capture date and location. The relationship between the litter size and maternal length was estimated using regression analysis.

\section{Embryonic development}

Embryos were sexed (when possible) and measured for total length to the nearest millimetre. Moreover, their round weight (RW) and yolk sac weight (YSW) were measured to the nearest centigram. The total length (TL) of embryos was correlated to both round weight and yolk sac weight (YSW) using regression analysis. The ANOVA test was used for significant differences among the mean embryonic length from one season to another. Sex ratio was determined and was compared with the 1:1 proportion using the chisquared test.

\section{RESULTS}

\section{Length frequency distributions and length-weight relationships}

The total sample consisted of 292 females and 233 males, while one hermaphrodite was found with internal male reproductive organs and no claspers. In females, the total length ranged from 182 to $779 \mathrm{~mm}$ $(500.5 \pm 125.9)$ and the round weight ranged from 22 to $2.900 \mathrm{~g}(786.2 \pm 546.7)$. In males, the total length ranged from 180 to $799 \mathrm{~mm}(462.5 \pm 87.9)$ and round weight ranged from 21 to $3.079 \mathrm{~g}(517.1 \pm 278.8)$ (Ta-
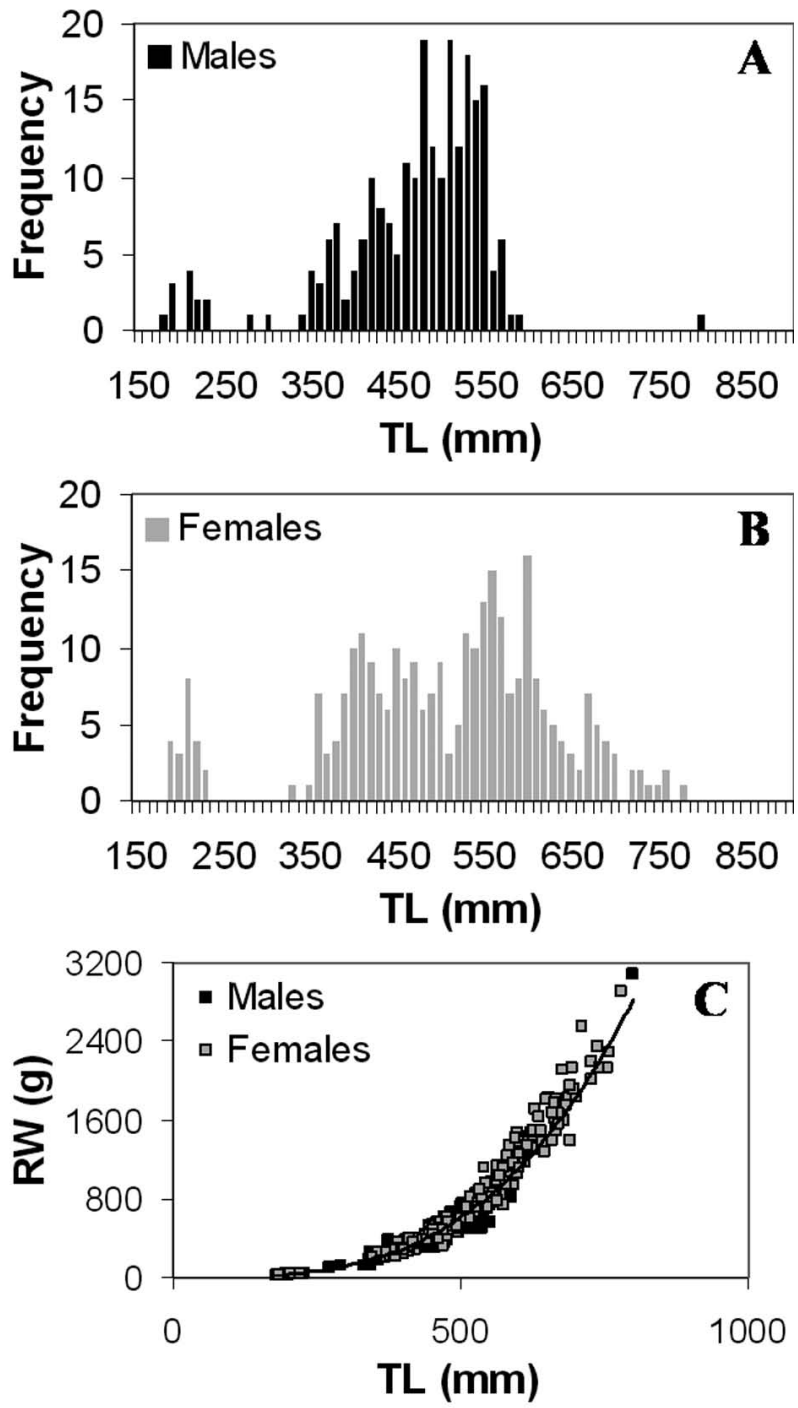

FIG. 2. - Total length frequency distribution of $(\mathrm{A})$ female $(\mathrm{N}=292)$ and $(\mathrm{B})$ male $(\mathrm{N}=232)$ Squalus blainvillei in the eastern Mediterranean Sea; (C) total length (TL)-round weight (RW) relationships of female $(\mathrm{N}=282)$ and male $(\mathrm{N}=221)$ Squalus blainvillei in the eastern Mediterranean Sea. 
ble 3). Length frequency distributions for females and males are shown in Figure 2. The results obtained from the Kolmogorov-Smirnov two-sample test indicate that males and females have significantly different length frequency distributions (Kolmogorov-Smirnov test, $P<0.05$ ).

A positive relationship was found between total length and round weight (Fig. 2). The length-weight relationships by sex were described by:

$\mathrm{RW}=8 \mathrm{E}-07 \mathrm{TL}^{3.30}\left(\mathrm{R}^{2}=0.99, \mathrm{n}=292\right)$ in females

$\mathrm{RW}=2 \mathrm{E}-06 \mathrm{TL}^{3.16}\left(\mathrm{R}^{2}=0.97, \mathrm{n}=233\right)$ in males.

Both sexes showed positive allometric growth since slope values (b) were greater than 3 ( $t$-test, $P<0.05$ ) The TL-RW relationships in females and males were found to be significantly different; there were statistically significant differences between the slopes (ANOVA, $P<0.01$ ) and between the intercepts (ANOVA, $P<0.01$ ) at the $99 \%$ confidence level.

\section{Sex ratio}

Overall females outnumbered males by a sex ratio (females:males) of 1.26:1, which was significantly different from a $1: 1$ sex ratio $\left(\chi^{2}=3.33, P<0.1\right)$. Likewise, females were dominant in the samples (Table 3 ) for each season, and the sex ratios were 1.13:1 in spring, 1.49:1 in summer, 1.28:1 in autumn and 1.26:1 in winter. The size and sex composition of longnose spiny dogfish were related. The Sex ratio showed an increase in the proportion of females in larger size groups. Most of the specimens that were smaller than $550 \mathrm{~mm}$ in TL were males whereas most of those that were larger than $550 \mathrm{~mm}$ in TL were females. In particular, males outnumbered females in lengths between 450 and 550 $\mathrm{mm}$, while no males were observed in lengths between 590 and $790 \mathrm{~mm}$ (Fig. 2).

\section{Maturity}

Out of 233 male longnose spiny dogfish, 68 (29.2\%) were classified as immature in stage I, $17(7.3 \%)$ as maturing in stage II, $61(26.2 \%)$ as mature in stage III and $86(37.1 \%)$ as adult in stage IV. Maturity stage was only unspecified in 1 male $(0.4 \%)$. The reproductive organ measurements taken on testes and claspers are given in Table 4. Relationships between total length and testis weight and total length and left clasper inner length were explored in order to see whether the measurements of these organ increased with total body length with the onset of maturity. In general, clasper length increased with total length and two groups can be noted according to the calcification of the claspers (Fig. 3). The first group corresponds to immature males with small, non-calcified claspers of less than $54 \mathrm{~mm}$. The second corresponds to mature and active males with fully calcified and rigid claspers of larger sizes (33-89 mm). A noticeable increase in clasper length occurs when specimens are slightly larger than 400 $\mathrm{mm}$, which indicates that male maturation has begun. Following this rapid increase, the claspers continue to grow but at a slower rate. Like clasper lengths, testis weight increased with total body length (Fig. 3).

Out of 292 female longnose spiny dogfish, 125 $(42.8 \%)$ specimens were classified in stage I, 55 $(18.8 \%)$ in stage II, $23(7.9 \%)$ in stage III, $13(4.5 \%)$ in stage IV, $4(1.4 \%)$ in stage V, $45(15.4 \%)$ in stage VI and15 (5.1\%) in stage VII. Maturity stage was unspecified in $12(4.1 \%)$ females. The measurements taken of ovaries and uteri are given in Table 5. Ovary weight and uterine width showed clear variation with reproductive stage. Ovary weight ranged from 0.01 to $4.4 \mathrm{~g}$ for immature specimens, from 0.3 to $5.9 \mathrm{~g}$ for maturing and from 5.6 to $240.8 \mathrm{~g}$ for mature specimens (stages III-VII). Uterus width varied from 0.2 to $6 \mathrm{~mm}$ for immature specimens, from 3 to $5 \mathrm{~mm}$ for

TABLE 4. - Range, mean value and standard deviation of reproductive organ measurements, gonadosomatic and hepatosomatic indices of male Squalus blainvillei in each maturity stage. N, number; SD, standard deviation.

\begin{tabular}{|c|c|c|c|c|c|c|}
\hline Characteristic & $\begin{array}{c}\mathrm{I} \\
\text { Range (N) }\end{array}$ & Mean & $\mathrm{SD}$ & $\begin{array}{c}\text { II } \\
\text { Range (N) }\end{array}$ & Mean & $\mathrm{SD}$ \\
\hline $\begin{array}{l}\text { Outer clasper length }(\mathrm{mm}) \\
\text { Inner clasper length }(\mathrm{mm}) \\
\text { Clasper base width }(\mathrm{mm}) \\
\text { Length of testicle }(\mathrm{mm}) \\
\text { Width of testicle }(\mathrm{mm}) \\
\text { Weight of testicles }(\mathrm{g}) \\
\text { Gonadosomatic index (GSI) } \\
\text { Hepatosomatic index (HSI) }\end{array}$ & $\begin{array}{c}2-15(59) \\
9-47(59) \\
1-11(57) \\
8-41(44) \\
2-7(7) \\
0-1.5(50) \\
0.04-0.5(39) \\
4.4-13.3(58)\end{array}$ & $\begin{array}{c}5.7 \\
23.1 \\
3.6 \\
24.6 \\
3.7 \\
0.4 \\
0.2 \\
8.4\end{array}$ & $\begin{array}{l}3 \\
8.3 \\
1.9 \\
7.5 \\
1.7 \\
0.4 \\
0.1 \\
2.1\end{array}$ & $\begin{array}{l}10-23(16) \\
35-54(16) \\
5-16(14) \\
25-57(16) \\
5-12(4) \\
0.5-3.7(16) \\
0.2-1.4(16) \\
6.9-16.8(16)\end{array}$ & $\begin{array}{c}17.5 \\
46.4 \\
7.4 \\
40.8 \\
8.1 \\
2.2 \\
0.6 \\
9.9\end{array}$ & $\begin{array}{l}2.9 \\
4.7 \\
2.7 \\
6.6 \\
2.4 \\
0.9 \\
0.3 \\
3\end{array}$ \\
\hline Hepatosomatic index (HSI) & $\begin{array}{c}\text { III } \\
\text { Range (N) }\end{array}$ & Mean & $\mathrm{SD}$ & $\begin{array}{c}\text { IV } \\
\text { Range (N) }\end{array}$ & Mean & $\mathrm{SD}$ \\
\hline $\begin{array}{l}\text { Outer clasper length }(\mathrm{mm}) \\
\text { Inner clasper length }(\mathrm{mm}) \\
\text { Clasper base width }(\mathrm{mm}) \\
\text { Length of testicle }(\mathrm{mm}) \\
\text { Width of testicle }(\mathrm{mm}) \\
\text { Weight of testicles }(\mathrm{g}) \\
\text { Gonadosomatic index (GSI) } \\
\text { Hepatosomatic index (HSI) }\end{array}$ & $\begin{array}{c}14-24(50) \\
39-58(50) \\
6-20(48) \\
10-75(55) \\
7-17(6) \\
1.8-10.9(55) \\
0.6-1.9(55) \\
5.8-19.6(55)\end{array}$ & $\begin{array}{c}18.4 \\
49.7 \\
9 \\
50.4 \\
11.6 \\
5.9 \\
1.3 \\
10.9\end{array}$ & $\begin{array}{l}2.3 \\
3.8 \\
2.6 \\
9.3 \\
3.8 \\
2.2 \\
0.3 \\
3\end{array}$ & $\begin{array}{c}13-25(81) \\
33-89(81) \\
3-15(81) \\
6.5-81(86) \\
8-22(19) \\
2.1-16.3(86) \\
0.7-2.5(81) \\
6-35.8(81)\end{array}$ & $\begin{array}{c}18.7 \\
52.7 \\
9 \\
55.9 \\
16.1 \\
8.2 \\
1.4 \\
11.7\end{array}$ & $\begin{array}{l}2.7 \\
5.7 \\
1.9 \\
9.3 \\
3.4 \\
2.8 \\
0.3 \\
4.1\end{array}$ \\
\hline
\end{tabular}



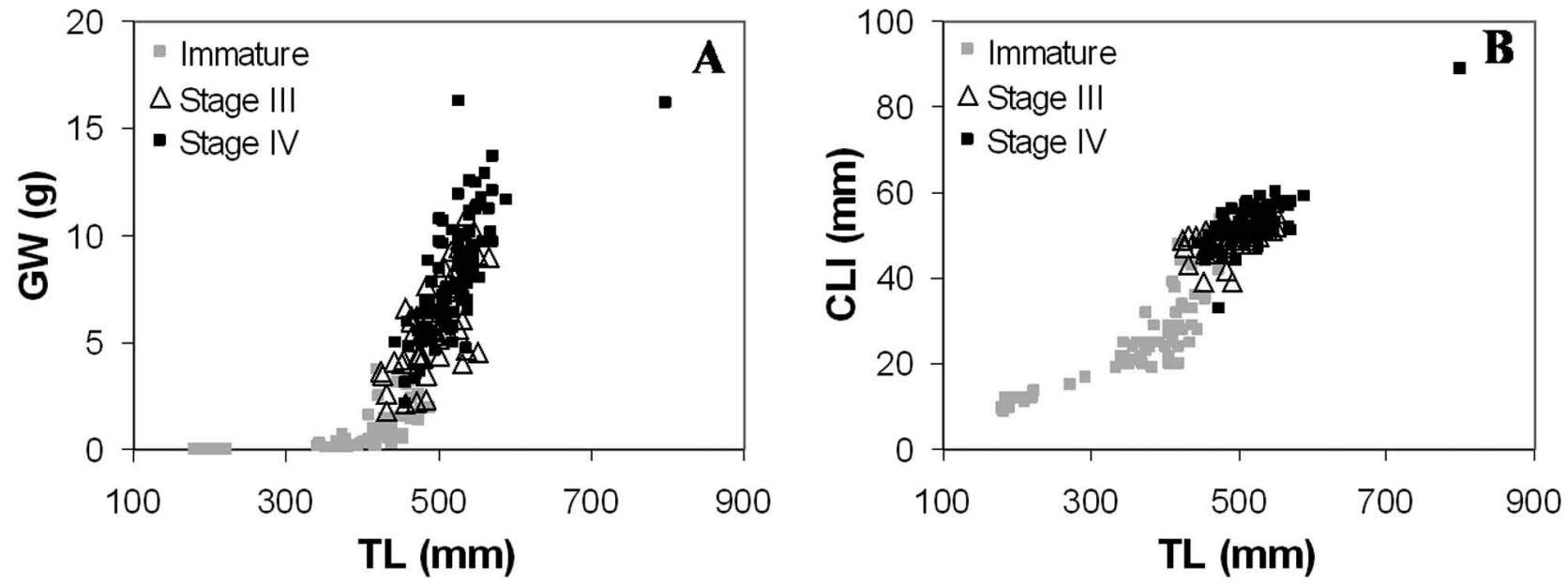

FIG. 3. - Relationships between total length (TL) with (A) gonad weight (GW) and (B) left clasper inner length (CLI) of male Squalus blainvillei in each maturity stage (immature: stage I and II).

maturing and from 3.1 to $79.4 \mathrm{~mm}$ for mature specimens. In general, the weight of ovaries and width of the uterus increased with total body length with the onset of maturity. In particular, both internal organ measurements increased rapidly from a TL of about $525 \mathrm{~mm}$ onward (Fig. 4).

In females, 135 specimens had immature ovaries, 53 had maturing ovaries, and 92 had mature ovaries. The development of oocytes within the ovary could be observed during gestation (stages IV-VI) and ovary weight tended to increase. It was noticed that, apart from one, all females that were caring embryos in their uteri had mature ovaries with large ripe oocytes at different stages of development ranging from 21 to $59 \mathrm{~mm}$ in diameter and from 2.9 to $32.6 \mathrm{~g}$ in weight (Fig. 5).

The two sexes differed in maturity composition as $35 \%$ of females and $63 \%$ of males were sexually mature. Specimens of both sexes were present in most

TABLE 5. - Range, mean value and standard deviation of reproductive organ measurements, gonadosomatic and hepatosomatic indices of female Squalus blainvillei in each maturity stage. N, number; SD, standard deviation.

\begin{tabular}{|c|c|c|c|c|c|c|c|c|c|}
\hline Characteristic & $\stackrel{\text { I }}{\text { Range (N) }}$ & Mean & SD & $\begin{array}{c}\text { II } \\
\text { Range (N) }\end{array}$ & Mean & SD & $\begin{array}{c}\text { III } \\
\text { Range (N) }\end{array}$ & Mean & SD \\
\hline Length of ovaries (mm) & $0.9-111(90)$ & 34 & 13 & $0.1-68(55)$ & 42.7 & 11 & $33-82(22)$ & 54.7 & 13 \\
\hline Width of ovaries (mm) & $3-15(38)$ & 8.1 & 3.4 & $7-30(12)$ & 13.5 & 5.8 & $16-45(10)$ & 28.1 & 7.3 \\
\hline Weight of ovaries (g) & $0-4.4(111)$ & 0.9 & 0.9 & $0.3-5.9(55)$ & 2.4 & 1.3 & $7-51(23)$ & 33.2 & 12.5 \\
\hline Length of uteri (mm) & $95-158(17)$ & 124.4 & 19.7 & $60(1)$ & - & - & $117-210(21)$ & 149 & 26 \\
\hline Width of uteri (mm) & $0.2-6(15)$ & 2 & 1.5 & $3-5(12)$ & 3.6 & 0.6 & 4-17 (12) & 11.5 & 3.7 \\
\hline Weight of uteri (g) & $0.1(1)$ & . & - & & - & - & $1.56-5.6(42)$ & 3.9 & 1.1 \\
\hline Gonadosomatic index (GSI) & $0-0.7(106)$ & 0.2 & 0.2 & $0.1-0.8(54)$ & 0.4 & 0.1 & $0.7-6.1(23)$ & 4.3 & 1.5 \\
\hline \multirow[t]{2}{*}{ Hepatosomatic index (HSI) } & $4.5-17.9(108)$ & 9.1 & 2.6 & $6.2-20.4(54)$ & 11.4 & 3.4 & $7.9-22.6(23)$ & 14.2 & 4.3 \\
\hline & $\begin{array}{c}\text { IV } \\
\text { Range (N) }\end{array}$ & Mean & SD & $\begin{array}{c}\text { V } \\
\text { Range (N) }\end{array}$ & Mean & SD & $\begin{array}{c}\text { VI } \\
\text { Range (N) }\end{array}$ & Mean & SD \\
\hline Length of ovaries (mm) & $36-112(12)$ & 59.4 & 19 & $39-67(4)$ & 49.5 & 9.1 & $34-121(44)$ & 59.6 & 15 \\
\hline Width of ovaries (mm) & $28(1)$ & - & - & - & - & - & $23-66(13)$ & 35.6 & 10 \\
\hline Weight of ovaries $(\mathrm{g})$ & 7.3-37.7 (13) & 13.3 & 7.9 & $8.5-18.6(4)$ & 14.1 & 4.5 & $5.6-240.8(44)$ & 59.7 & 45 \\
\hline Length of uteri (mm) & $135-205(13)$ & 167.5 & 22 & $141-230(4)$ & 185.9 & 29 & $106-340(44)$ & 178.7 & 38.4 \\
\hline Width of uteri (mm) & $27-59(6)$ & 42.2 & 10 & $65(1)$ & - & - & $3.1-79.4(23)$ & 41.2 & 14 \\
\hline Weight of uteri (g) & $3.7-107.2(13)$ & 40.1 & 27 & $14.8-110.8(4)$ & 77 & 28.7 & $5.2-172(41)$ & 58.1 & 33.9 \\
\hline Gonadosomatic index (GSI) & $0.8-2.9(13)$ & 1.3 & 0.6 & $0.9-1.6(4)$ & 1.18 & 0.3 & $0.9-14.7(44)$ & 5.3 & 2.9 \\
\hline \multirow[t]{2}{*}{ Hepatosomatic index (HSI) } & $9.7-22.9(13)$ & 15 & 3.9 & $14.5-17.1(4)$ & 16.3 & 1.2 & $8.3-21.2(44)$ & 14.5 & 3.5 \\
\hline & $\begin{array}{c}\text { VII } \\
\text { Range (N) }\end{array}$ & Mean & SD & & & & & & \\
\hline Length of ovaries (mm) & $43-80(15)$ & 61.5 & 10.3 & & & & & & \\
\hline Width of ovaries (mm) & 39 (1) & - & - & & & & & & \\
\hline Weight of ovaries (g) & $14.5-105.6(15)$ & 53.2 & 23.8 & & & & & & \\
\hline Length of uteri (mm) & $141-233(15)$ & 171 & 23.9 & & & & & & \\
\hline Width of uteri (mm) & $10-32(5)$ & 17.3 & 8.5 & & & & & & \\
\hline Weight of uteri (g) & $4.4-26.5(15)$ & 7.2 & 4.2 & & & & & & \\
\hline Gonadosomatic index (GSI) & $1-11.2(15)$ & 5.8 & 2.6 & & & & & & \\
\hline Hepatosomatic index (HSI) & $10.2-22.5(15)$ & 15.1 & 3.3 & & & & & & \\
\hline
\end{tabular}



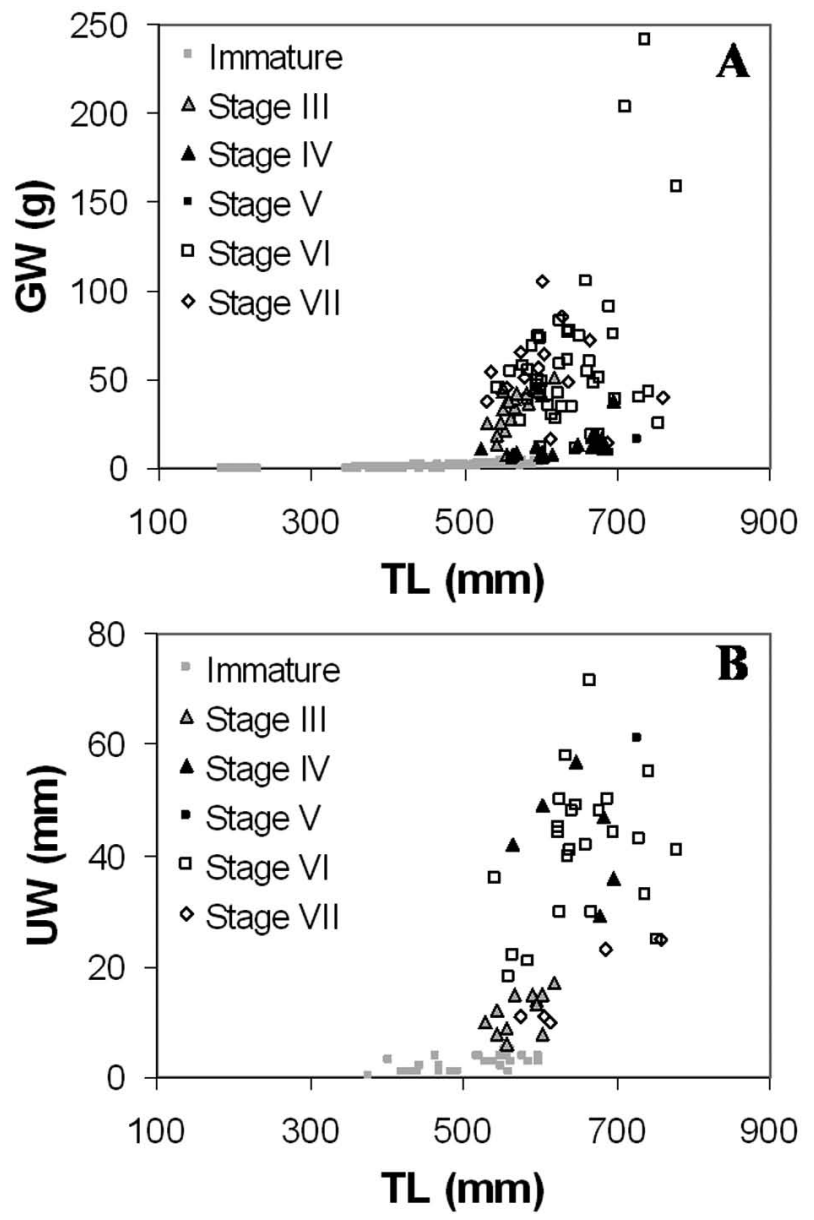

FIG. 4. - Relationships between total length (TL) with (A) gonad weight (GW) and (B) left uterus width (UW) of female Squalus blainvillei in each maturity stage (immature: stage I and II).

reproductive stages during the entire year although relative frequencies by season varied considerably (Fig. 6). The percentage of mature females and males for each season was respectively: spring $41 \%$ and $76 \%$, summer $43 \%$ and $46 \%$, autumn $37 \%$ and $69 \%$, winter $10 \%$ and $35 \%$.

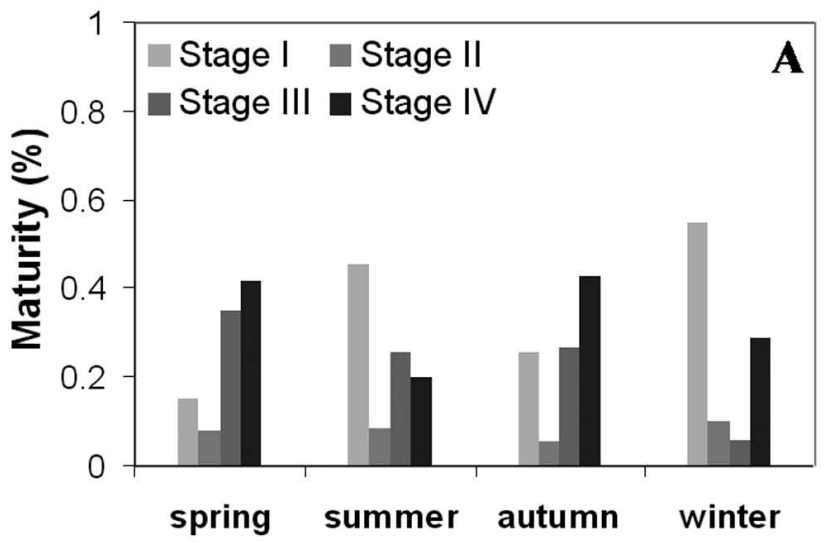

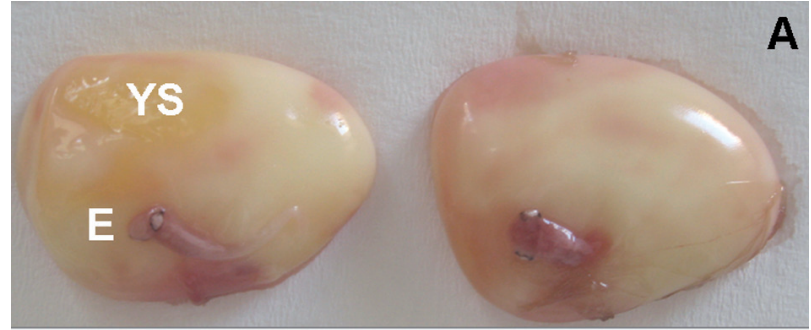
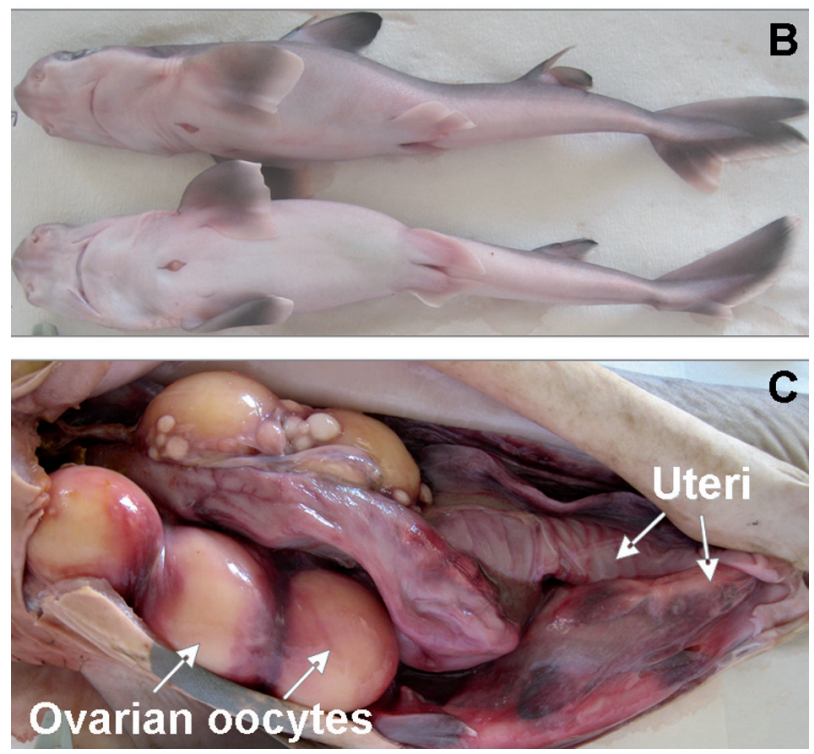

FIG. 5. - Reproductive organs of a female longnose spiny dogfish, Squallus blainvillei, and embryos: (A) two embryos with their large external yolk sacs in an early development stage; (B) full-term embryos with the external yolk sacs absorbed; (C) reproductive organs of a gravid female (stage VI) with mature ovaries and uteri containing developing embryos. In ovaries there are five large ripe oocytes along with smaller immature and maturing white-yellowish oocytes.

\section{Gonadosomatic and hepatosomatic indices}

The GSI reached higher values in females than in males, and ranged from 0.07 to $14.7(2.1 \pm 2.7)$ in females and from 0.04 to $2.5(1.1 \pm 0.6)$ in males (Table 4 and 5). At the $95 \%$ confidence level there was

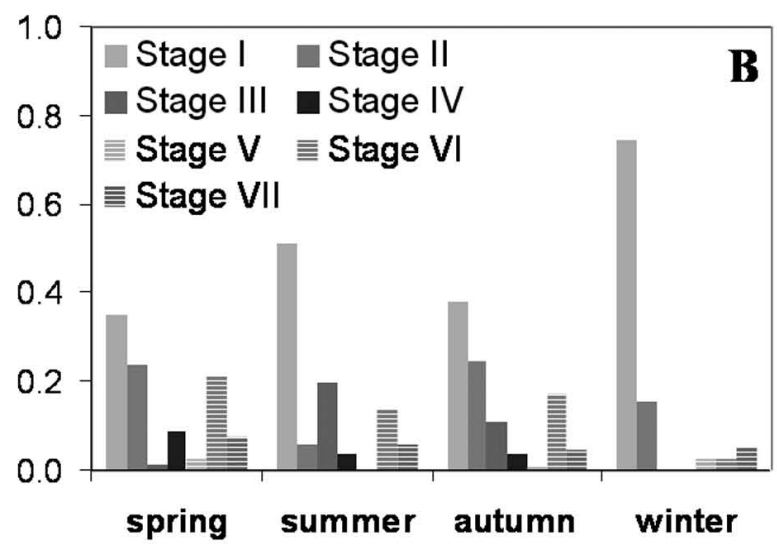

FIG. 6. - Percentage of (A) female $(\mathrm{N}=280)$ and $(\mathrm{B})$ male $(\mathrm{N}=232)$ Squalus blainvillei in each maturity stage for each season in the eastern Mediterranean Sea. 

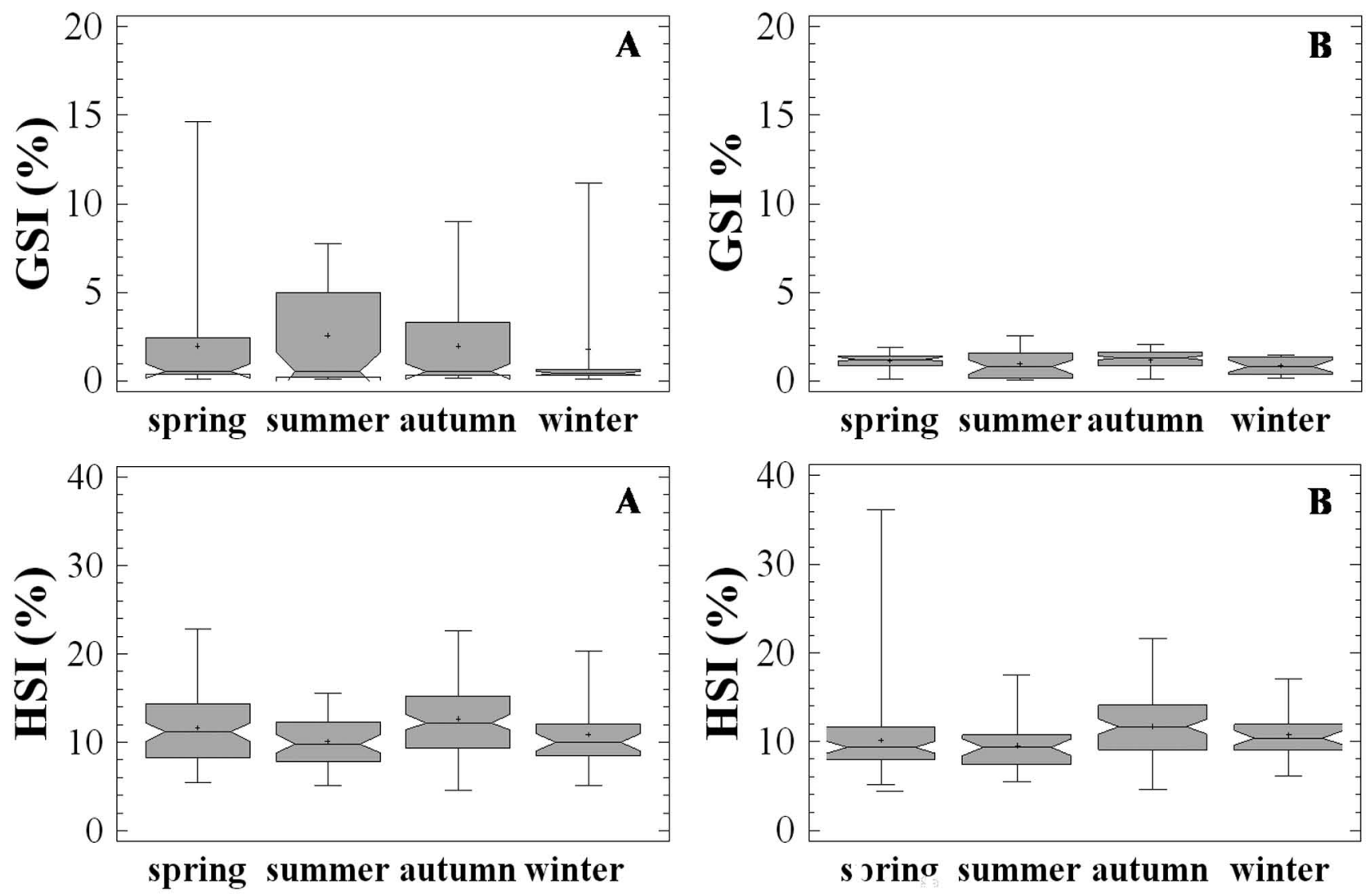

FIG. 7. - Gonadosomatic index (\%) and hepatosomatic index (\%) in each sampling season for (A) female and (B) male Squalus blainvillei; asterisk $\left(^{+}\right)$: mean, horizontal line: median, grey area: $50 \%$ of the values, notch: $95 \%$ confidence level for median, vertical line: minimum, maximum.

a statistically significant difference between females and males in mean GSI values (ANOVA, $P<0.05$ ). Females and males reached maturity when the GSI value was equal to 0.79 and 1.38 respectively. In females, the GSI displayed its highest value in May (14.7), while in males GSI displayed its highest values in June (2.5). Statistically significant differences were not found in mean GSI from one season to another in either females (ANOVA, $P=0.5802$ ) or males (ANOVA, $P=0.1228$ ) (Fig. 7). Moreover, there were statistically significant differences in the mean GSI values from one maturity stage to the next at the $95.0 \%$ confidence level (in all cases: ANOVA, $P<0.05)$. In females, the GSI reached higher values in stages VI and VII, while in males the GSI reached higher values in stage III.

The longnose spiny dogfish has a relatively large liver, which constitutes up to $35.6 \%$ of the body weight. The HSI reached higher values in males, ranging from 4.4 to $35.8(10.4 \pm 3.5)$, than in females, ranging from 4.6 to $22.9(11.8 \pm 4.1)$. At the $95 \%$ confidence level, the mean HSI values (ANOVA, $P<0.05)$ were statistically different between females and males. In females, the highest HSI values were recorded in April (22.9) and lowest in October (4.6), while in males the highest values were recorded in May (35.8) and lowest in November (4.4). Statistically significant differences were found in mean
HSI from one season to the next in both females (ANOVA, $P<0.05$ ) and males (ANOVA, $P<0.05$ ) at the $95.0 \%$ confidence level (Fig. 7). Moreover, there were statistically significant differences in mean HSI values from one stage of maturity to another at the $95.0 \%$ confidence level in both females and males (in all cases: ANOVA, $P<0.05)$.

\section{Length at sexual maturity}

Males attained maturity at a smaller size than females. The smallest sexually mature female was 523 $\mathrm{mm}$ in TL and $770 \mathrm{~g}$ in RW while the smallest sexually mature male was $425 \mathrm{~mm}$ in TL and $388 \mathrm{~g}$ in RW. At lengths greater than $618 \mathrm{~mm}$ all females were mature while all males were mature at lengths greater than 490 mm. In a total of 100 mature females, the total length (TL) ranged from 523 to $779 \mathrm{~mm}(620.0 \pm 58.9)$, while in 147 mature males, the total length (TL) ranged from 425 to $799 \mathrm{~mm}(511.4 \pm 41.5)$. Mean total length at $50 \%$ maturity was estimated at $564.4 \mathrm{~mm}$ for females and $457.7 \mathrm{~mm}$ for males (Fig. 8).

\section{Fecundity}

Data were obtained from 47 litters and $156 \mathrm{em}$ bryos. Litter size (uterine fecundity) ranged from 1 to 

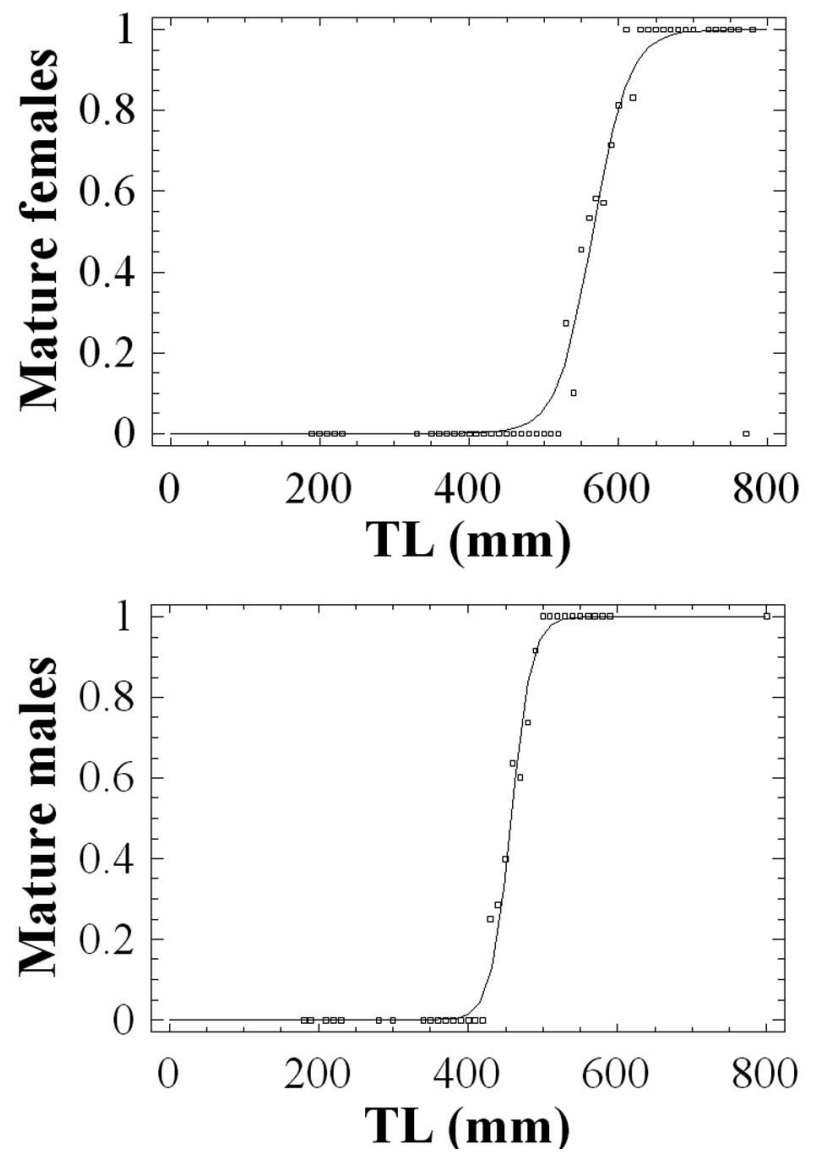

FIG. 8. - Proportion of mature female and male Squalus blainvillei against total length (TL) in the eastern Mediterranean Sea.

6 embryos with a mean value of $3.3 \pm 1.3$ embryos. The number of embryos in each uterus was different. In 45 females, $82(54.7 \%)$ embryos occupied the right uterus while 68 (45.3\%) embryos occupied the left uterus, and the resulting ratio $0.83: 1$ of embryos occupying the left to the right uteri was significantly different from a $1: 1$ ratio $\left(\chi^{2}\right.$-test, $\left.P<0.1\right)$. Most gravid females had 4 embryos in their uteri, and a low correlation was found between female total length and number of embryos occupying the uteri. Litter size (LS) increased with maternal TL according to the equation:

$$
\mathrm{LS}=0.0053 \mathrm{TL}, \mathrm{R}^{2}=0.17, \mathrm{n}=47 \text {. }
$$

Ovarian fecundity ranged from 1 to 7 ripe oocytes with a mean value of $3.4 \pm 1.5$ ripe oocytes per female. 3 ripe oocytes were counted in the ovaries of the majority of females $(\mathrm{N}=28)$. We observed that both ovaries are functional. In the right ovaries, there were from 1 to 6 $(2 \pm 1.1)$ ripe oocytes $(\mathrm{N}=131)$. In the left ovaries, there were from 1 to $5(1.9 \pm 0.9)$ ripe oocytes $(\mathrm{N}=145)$. The resulting ratio $(1.1: 1)$ of the number of ripe oocytes occupying the left to those occupying the right ovaries was significantly different from a $1: 1$ ratio $\left(\chi^{2}=0.13\right.$, $P=0.931)$.
The sizes of 746 oocytes were measured in a total of 107 females. Out of these, 277 were ripe oocytes, 321 maturing and 148 immature. The ripe oocytes occupied the mature ovaries of 92 females. In right ovaries, ripe oocytes $(\mathrm{N}=131)$ ranged from 21 to $42 \mathrm{~mm}(30.3 \pm 5.6)$ in diameter and from 2.93 to $32.6 \mathrm{~g}(13.3 \pm 7.1)$ in weight, while in left ovaries, ripe oocytes $(\mathrm{N}=145)$ ranged from 21 to $59 \mathrm{~mm}(29.8 \pm 6.2)$ in diameter and from 3.5 to $32.4 \mathrm{~g}(12.5 \pm 6.4)$ in weight. Statistically significant differences were not found in the mean diameter (ANOVA, $P=0.479$ ) or mean weight (ANOVA, $P=0.315$ ) of ripe oocytes between the right and left ovaries at the $95.0 \%$ confidence level. The diameter $\left(\mathrm{D}_{\mathrm{o}}\right)$ and weight $\left(\mathrm{W}_{\mathrm{o}}\right)$ of ripe and maturing oocytes showed a positive relationship (Fig. 9):

$$
\mathrm{W}_{\mathrm{o}}=0.0007 \mathrm{D}_{\mathrm{o}}^{2.83}, \mathrm{R}^{2}=0.88 \text {. }
$$

\section{Embryonic growth, gestation and parturition}

In a total of 47 litters, 156 embryos were recorded (67 females, 69 males, 20 unsexed), ranging from 37 to $209 \mathrm{~mm}$ in total length $(139.9 \pm 44.2)$ and from 0.1 to $42.5 \mathrm{~g}(14.7 \pm 9.9)$ in weight. The sex ratio of female to male pups was $0.97: 1$ and was not significantly different from a 1:1 sex ratio $\left(\chi^{2}=0.01, P=0.903\right)$.

Sex can be distinguished in embryos with a total length over $37 \mathrm{~mm}$. All embryos in a litter were generally of similar size and in the same developmental stage. The external yolk sac weighed 21.8 to 32.3 $\mathrm{g}$ in the smallest embryos (Table 6). By the end of the gestation period, the external yolk sac was completely absorbed and had regressed to a scar (Fig. 6). Out of the 156 embryos, 2 embryos, measuring 205 and $209 \mathrm{~mm}$ in total length, had fully absorbed yolk sac, while 5, measuring 159, 171, 172, 184 and 185 $\mathrm{mm}$ in total length, had an almost absorbed yolk sac weighing $0.5,0.1,0.4,0.8$ and $0.4 \mathrm{~g}$ respectively. All near-term embryos were oriented with their head facing posteriorly. Embryo length (TL) and yolk sac

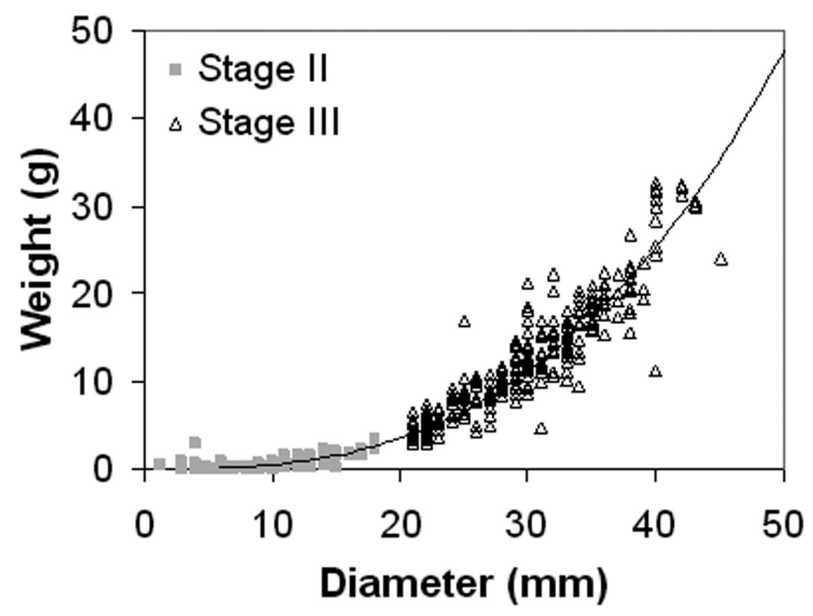

FIG. 9. - Relationship between diameter and weight of maturing (Stage $\mathrm{II}, \mathrm{N}=321$ ) and ripe (Stage III, $\mathrm{N}=277$ ) oocytes. 
TABLE 6. - Mean value, standard deviation and range of embryo weight with and without their yolk sac weight (YSW) as well as yolk sac weight (YSW) of Squalus blainvillei in each size class.

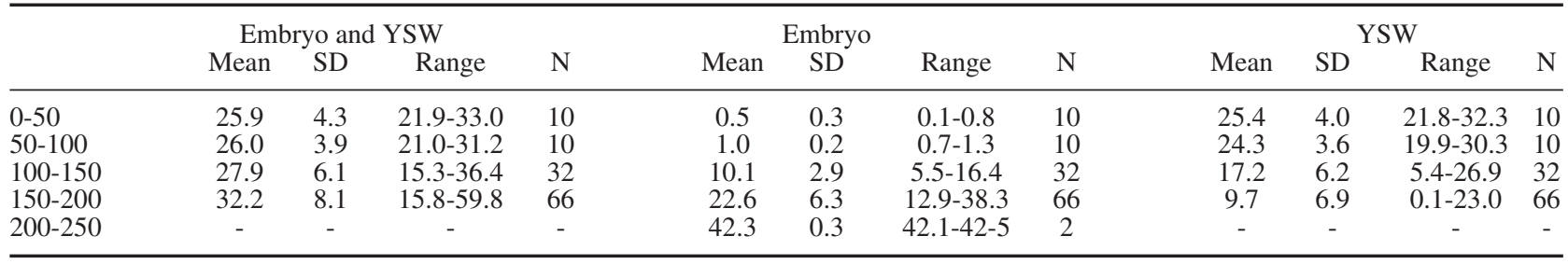
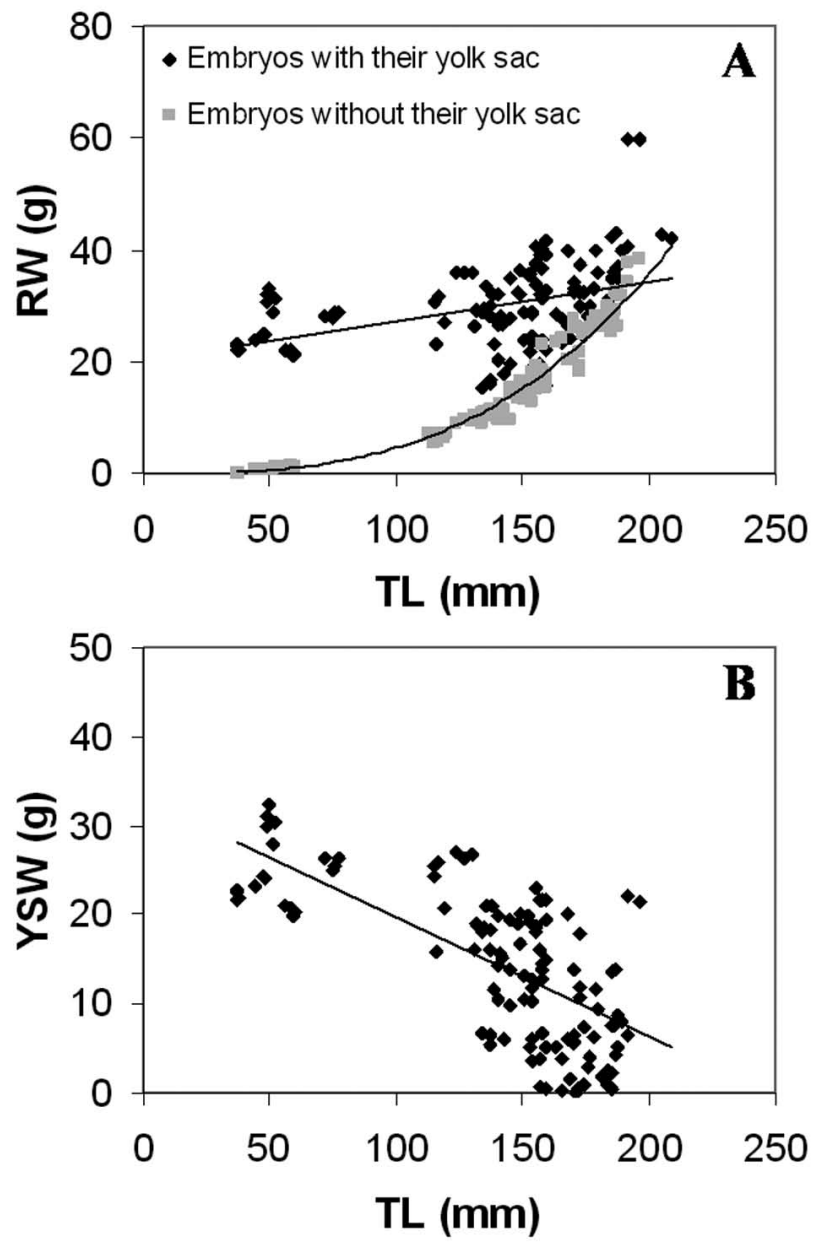

FIG. 10. - (A) Relationships between total length (TL) and round weight (RW) with and without the yolk sac of Squalus blainvillei pups; (B) Relationship between total length (TL) and yolk sac weight (YSW) of Squalus blainvillei pups.

weight (YSW) were negatively correlated $\left(\mathrm{R}^{2}=0.48\right.$, $\mathrm{YSW}=34.5-0.14 \mathrm{TL}$ ) (Fig. 10). The mean value, standard deviation and range of embryo weights with and without the yolk sac in four length classes are shown in Table 6. Statistically significant differences were not found between the mean weight of embryos with their yolk sac from one length class to the next (ANOVA, $P=0.369$ ) at the $95.0 \%$ confidence level. The mean embryo weight with the yolk sac ranged between a lower mean value of $25.9 \pm 4.3 \mathrm{~g}$ in length class $0-50 \mathrm{~mm}$ and a higher mean value of $32.2 \pm 8.1$ $\mathrm{g}$ in length class $150-200 \mathrm{~mm}$. Embryo length (TL)

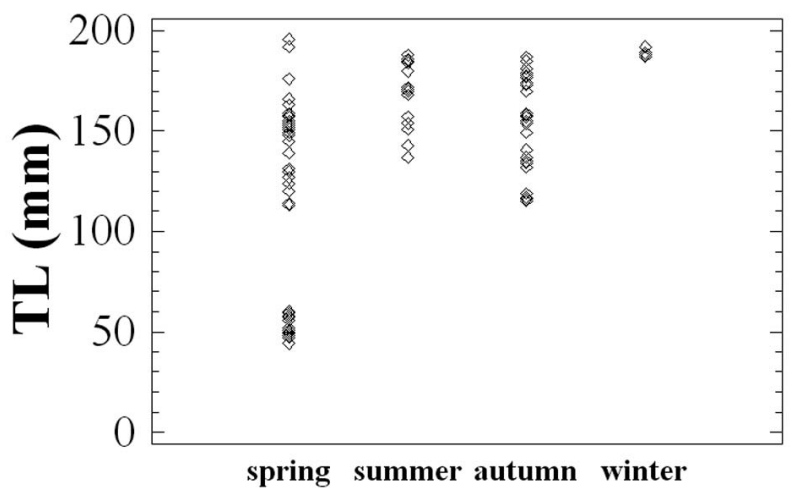

FIG. 11. - Total lengths (TL) of Squalus blainvillei pups distributed by season.

and round weight including the yolk sac $\left(\mathrm{RW}_{\mathrm{YS}}\right)$ were not highly correlated. On the contrary, embryos without the yolk sac increased exponentially (Fig. 10) with length, showing a high correlation between total length (TL) and round weight (RW):

$$
\begin{array}{ll}
\mathrm{RW}_{\mathrm{YS}}=20.2+0.071 \mathrm{TL} & \left(\mathrm{R}^{2}=0.17, \mathrm{n}=156\right) \\
\mathrm{RW}=6 \mathrm{E}-06 \mathrm{TL}^{2.95} & \left(\mathrm{R}^{2}=0.98, \mathrm{n}=156\right) .
\end{array}
$$

Large embryos over $180 \mathrm{~mm}$ TL were observed during all seasons. The largest embryo in spring was $209 \mathrm{~mm}$, in summer $188 \mathrm{~mm}$, in autumn $187 \mathrm{~mm}$ and in winter $192 \mathrm{~mm}$. On the other hand, small embryos below $50 \mathrm{~mm}$ in TL were found only during spring, in March and April. A large variation in embryo total length by season is shown in Figure 11. Statistically significant differences were found between the mean embryo total length from one season to the next (ANOVA, $P<0.05$ ) at the $95.0 \%$ confidence level. The mean total length of embryos ranged between a lower mean value of $121.9 \pm 47.7 \mathrm{~mm}$ in spring and a higher mean value of $189 \pm 2.2 \mathrm{~mm}$ in winter. During summer and autumn, the mean total lengths of embryos were $167.8 \pm 17.9 \mathrm{~mm}$ and $155.7 \pm 23.1 \mathrm{~mm}$ respectively.

A total of 33 juveniles ranging from 180 to $229 \mathrm{~mm}$ in total length $(202.94 \pm 12.96)$ were observed in the trawl catches at depths from 238 to $275 \mathrm{~m}$ in the area of the North Evoikos Gulf on 14 December 2009. The dissections revealed the presence of a small internal yolk sac attached to their stomach, which indicates that these are newborn specimens (Fig. 12). 

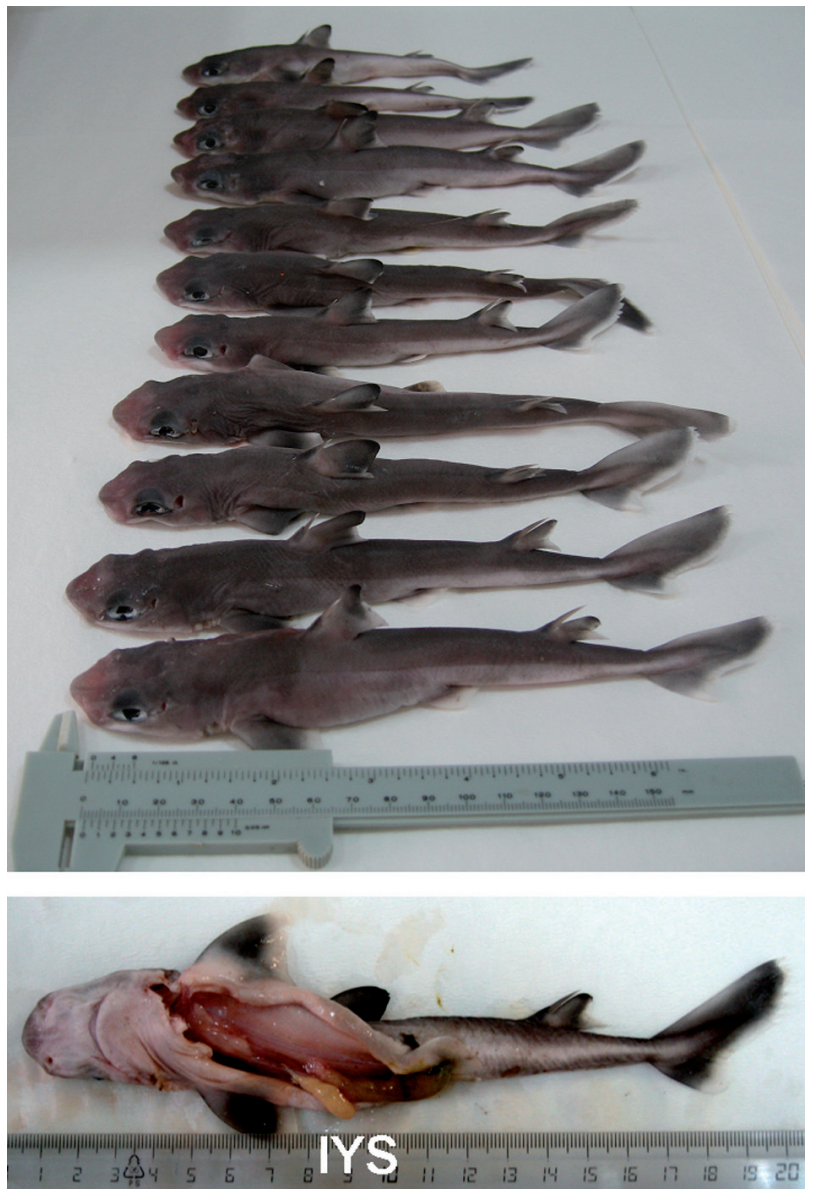

FIG. 12. - (A) New-born juveniles of Squalus blainvillei caught in the South Evoikos Gulf during a trawl survey in a depth range from 238 to $275 \mathrm{~m}$; (B) dissection of a new-born specimen measuring 198 $\mathrm{mm}$ in TL and $35 \mathrm{~g}$ in RW; its internal yolk sac (IYS) was $17 \mathrm{~mm}$ in length, $7 \mathrm{~mm}$ in width and weighed $0.11 \mathrm{~g}$.

\section{DISCUSSION}

Our findings revealed that longnose spiny dogfish in the eastern Mediterranean Sea enter the trawl fishery in their first year of life, and the catches consist of both juveniles and adults of both sexes. Although males and females had similar minimum $(182-180 \mathrm{~mm})$ and maximum (779-799 $\mathrm{mm}$ ) lengths, the size compositions and sex ratios were different. The female dominance, especially in specimens larger than $550 \mathrm{~mm}$, and the strong dominance of males with a total length between 450 and $550 \mathrm{~mm}$, could reflect a sexual segregation of the species with depth or sexual assemblages in different areas. Several authors have described sex frequencies that differ with depth or area in squalid sharks (Avsar, 2001; Clarke et al., 2001; Yano, 1995; Bañón et al., 2006). The catch of 33 newborn specimens during one trawl survey may indicate that there is a nursery area of the species in the South Evoikos Gulf.

Previous studies on the longnose spiny dogfish in the Mediterranean Sea report larger maximum sizes than those found in the present study and sexual dimor- phism with females being larger than males (Quignard, 1971; Cannizaro et al., 1995; Sion et al., 2003). According to Tortonese (1956), the maximum total length this species reaches is $960 \mathrm{~mm}$, while according to Cannizaro et al. (1995) the longest female measured $920 \mathrm{~mm}$ and the longest male $735 \mathrm{~mm}$ in total length. In our samples, although most males ranged from 180 to $589 \mathrm{~mm}$ in total length, there was one male, measuring $799 \mathrm{~mm}$ and $3.079 \mathrm{~g}$, that was slightly larger than the largest female. This male specimen was caught along with two other sharks of $530 \mathrm{~mm}$ and $450 \mathrm{~mm}$ during a trawl survey in the North Aegean Sea at a depth between 421 and $512 \mathrm{~m}$ in spring.

As far as length-weight relationships are concerned, positive relationships were found between total length and round weight. The $b$ values were higher than 3 , which shows that there is allometric growth in both males and females. The relationships of TL-RW for females and males were significantly different. Similar results were found by Sion et al. (2003) in the Ionian Sea and Cannizaro et al. (1995) in the Sicilian Channel.

The overall length frequency distributions, lengthweight relationships and examination of maturity stages indicate that the longnose spiny dogfish shows sexual dimorphism in the Mediterranean Sea, with females growing larger than males and reaching maturity at a larger size. The only available data on mean total length at $50 \%$ maturity comes from Cannizaro et al. (1995), in which values of 570-580 mm for females and $450-460 \mathrm{~mm}$ for males were found. Our study showed similar results with a mean total length at 50\% maturity of $564.4 \mathrm{~mm}$ for females and 457.7 for males, which confirms that females reach sexual maturity at larger sizes than males. This difference in size at maturity between the two sexes has also been noted in other elasmobranches and is common in the squaloid species Squalus acanthias, Centrophorus granulosus, Centrophorus squamosus, Centroscymnus coelolepis (Capapé, 1985; Girard and Du Buit, 1999; Chatzispyrou and Megalofonou, 2005; Megalofonou and Chatzispyrou, 2006).

Our results corroborate that the reproductive strategy of the longnose spiny dogfish involves the production of few embryos and continuous reproductive activity during the year (Cannizzaro et al., 1995). It has been confirmed as an aplacental viviparous species with a maximum of six pups per litter. All females had two almost equally developed ovaries. Oocytes in ovaries continued to develop throughout gestation and gravid females with developing oocytes in their active ovaries also had from one to seven ripe oocytes that were similar in size. The largest ripe oocyte weighed was $32.6 \mathrm{~g}$. It is known that some female elasmobranches continue to produce unfertilized oocytes as a source of nutrition for the embryos developing within the uteri (Hamlett and Koob, 1999). However, this does not seem to be the case here, as we did not observe unfertilized oocytes in the uteri containing embryos. Therefore, we concluded that embryos of 
the longnose spiny dogfish obtained nourishment from their large external yolk sac. The fact that the weight of the near-term embryos slightly exceeded the largest oocyte weight or the weight of the external yolk sac during early embryonic development corroborates our observations. Within strictly lecithotrophic species, to produce larger ova is the primary and almost the only mechanism for producing larger newborns, which have a better chance of survival (Guallart and Vicent, 2001).

The large variations in embryo length in any season especially during spring indicates that the gestation period of the longnose spiny dogfish is long and probably exceeds 12 months. Moreover, the presence of near-term embryos during all seasons revealed that parturition occurs throughout the year. Cannizzaro et al. (1995) reported a gestation period of 17 months and a continuous reproductive period throughout the year with spring the preferred season for reproduction in the Sicilian Channel. The characteristic of a long gestation period has also been observed in other squaloids species, and Squalus acantias and Centrophorus granulosus have gestation periods lasting two years (Guallart and Vicent, 2001; Jones and Ugland, 2001).

Among mature females, those with developing embryos as well as post-natal females had the largest ovary weights and the highest gonadosomatic indices (Table 5). This suggests that mating and ovulation occurs soon after parturition, and therefore the longnose spiny dogfish might have a small or no resting period after parturition. In several squaloid species, oocytes in ovaries continue to develop throughout gestation, since most gravid females carry large embryos and large oocytes simultaneously, which suggests that they ovulate soon after parturition (Capapé, 1985; Guallart and Vicent, 2001). Capapé (1985) reported that along the coasts of Tunisia the reproduction cycle of Centrophorus granulosus is similar to that of Squalus blainvillei and Heptanchias perlo (Bonnaterre, 1788). Given that mature females with either large near-term embryos or empty after-birth uteri were observed during all seasons, it could be assumed that mating and ovulation occur throughout the year. This also confirms the prolonged reproductive period which has already been mentioned in previous studies (Quignard, 1971, Cannizaro et al., 1995, Sion et al., 2003). This assumption could be corroborated by the fact that sexually mature specimens of both sexes with mature gonads and high GSI are present in high proportions in every season of the year (Fig. 6).

Continuous or prolonged reproductive activity throughout the year with one or two peaks is well known for several species of sharks. According to Wourms (1977) chondrichthyans may have one of the three basic types of reproductive cycle: (1) reproduction throughout the year or in most months; (2) a poorly defined annual cycle with one or two peaks; or (3) a well defined annual or biennial cycle. Our results indicate that the longnose spiny dogfish has continuous reproductive activity with no defined peaks.
Spring was assumed to be the preferable season for the reproduction of longnose spiny dogfish in the Sicilian Channel (Cannizaro et al., 1995). In this season $21.9 \%$ of females and $44 \%$ of males were sexually mature and ready for reproduction. In the present study, high percentages of sexually mature females were found during spring (41\%), summer (43\%) and autumn (37\%) (Fig. 6). Considering these observations it could be assumed that the reproductive activity of the longnose spiny dogfish in the eastern Mediterranean Sea is more intensive and extended than in the Sicilian Channel. In our study the proportion of males ready for reproduction was much larger than that of females during all seasons. Cannizaro et al. (1995) reported similar results but lower values.

Abnormalities in the reproductive system are rare among elasmobranches; however, examination of the reproductive organs yielded some unusual results. In particular, in one specimen, observation of the reproductive organs revealed an abnormality in clasper formation without evident abnormalities in the gonad morphology. Different expressions of hermaphroditism have been reported in shark species (Chatzispyrou and Megalofonou, 2005; Jones et al., 2005).

In the present study, statistically significant differences were found in mean GSI and HSI values in both sexes from one stage of maturity to the next, but not from one season to another. The liver seems to be a key organ in reproduction, especially in the case of females because it is involved in yolk production through production of vitellogenin, the yolk precursor (Koob and Callard, 1999). Although the highest HSI value (35.8\%) was found in a male measuring $799 \mathrm{~mm}$, our results also showed that the liver is slightly larger in females than in males with mean HSI values of $11.81 \%$ and $10.44 \%$ respectively. It is assumed that females invest a lot of energy into producing gonadic products, and variation in the HSI is considered to be a normal situation for them as they attain maturity.

Uterine fecundity ranged from 1 to 6 embryos $(3.32 \pm 1.32)$ and it was lower than that described by Ebert et al. (2002) in South African waters, where a large female of $956 \mathrm{~mm}$ in total length was carrying 8 near-term embryos ranging from 249 to $256 \mathrm{~mm}$ in total length. In the present study, out of the 45 females that were carrying embryos, two embryos, measuring $205 \mathrm{~mm}$ and $209 \mathrm{~mm}$, were found with fully absorbed yolk sacs, while the largest embryo with a yolk sac was $185 \mathrm{~mm}$ in total length. According to Cannizaro et al. (1995) the embryo yolk sac is always present up to lengths of about $200 \mathrm{~mm}$; however, according to Quignard (1971), at term the embryo measures 210 to $240 \mathrm{~mm}$, and according to Ranzi (1932) it measures $190 \mathrm{~mm}$.

The minimum lengths of juvenile longnose spiny dogfish found in our catches were $182 \mathrm{~mm}$ for females and $180 \mathrm{~mm}$ for males; these small specimens did not have an external yolk sac but did have internal yolk sacks. In the Sicilian channel the smallest female and 
male were $140 \mathrm{~mm}$ and $145 \mathrm{~mm}$ respectively, both with external yolk sacs (Cannizaro et al., 1995), while in the Ionian Sea the smallest individuals of both sexes without external yolk sacs measured $190 \mathrm{~mm}$ (Sion et al., 2003). Considering the above information, it could be assumed that in the eastern Mediterranean Sea, at-term embryos are smaller than in all other areas studied in the western-central Mediterranean Sea. Moreover, based on the lengths of the smallest new born $(180 \mathrm{~mm})$ caught and the largest embryo (209 $\mathrm{mm}$ ) found, it could be speculated that the total length at birth of the longnose spiny dogfish ranges between 180 and $210 \mathrm{~mm}$.

\section{ACKNOWLEDGEMENTS}

We are grateful to the fishermen for all their support onboard their fishing vessels and the students at the Department of Biology who collaborated with sampling and measuring. We also thank the two anonymous reviewers for improvements to the manuscript. The present study was partially funded through the Operational Programme for Education and Initial Vocational Training (O.P. "Education") in the framework of the project "Pythagoras II - Support of University Research Groups with 75\% from European Social Funds and 25\% from National Funds.

\section{REFERENCES}

Avsar, D. - 2001. Age, growth, reproduction and feeding of the spurdog (Squalus acanthias Linnaeus, 1758) in the south-eastern Black Sea. Estuar. Coast. Shelf Sci., 52: 269-278.

Bañón, R., C. Piñero and M. Casas. - 2006. Biological aspects of deep-water sharks Centroscymnus coelolepis and Centrophorus squamosus in Galician waters (north-western Spain). J. Mar. Biol. Ass. U.K., 86: 843-846.

Capapé, C. - 1985. Nouvelle description de Centrophorus granulosus (Schneider, 1801) (Pisces, Squalidae). Données sur la biologie de la reproduction et le régime alimentaire des spécimens des côtes tunisiennes. Bull. Inst. Natl. Sci. Tech. Oceanogr., 12 97-141.

Cannizaro, L., P. Rizzo, D. Levi and S. Gancitano. - 1995. Age determination and growth of Squalus blainvillei (Risso, 1826). Fish. Res., 23: 113-125.

Chatzispyrou, A. and P. Megalofonou. - 2005. Sexual maturity, fecundity and embryonic development of the spiny dogfish, Squalus acanthias, in the eastern Mediterranean Sea. J. Mar. Biol. Ass. U.K. 85: 1155-1161.

Clarke, M.W., P.L. Connolly and J.J. Bracken. - 2001. Aspects of reproduction of the deep water sharks Centroscymnus coelolepis and Centrophorus squamosus from west of Ireland and Scotland. J. Mar. Biol. Ass. U.K., 81: 1019-1029.

Compagno, L.J.V. - 1984. FAO species catalogue. Vol. 4. Sharks of the world: an annotated and illustrated catalogue of shark species known to date. Part I. Hexanchiformes to Lamniformes. FAO Fisheries Synopsis (125), 4, part 1

Compagno, L.J.V., M. Dando and S. Fowler. - 2005. Sharks of the World. Collins, London.

Dulvy, N.K., J.K. Baum, S. Clarke, L.J.V. Compagno, E. Cortés, A Domingo, S. Fordham, S. Fowler, M.P. Francis, C. Gibson, J. Martínez, J.A. Musick, A. Soldo, J.D. Stevens and S. Valenti. - 2008. You can swim but you can't hide: The global status and conservation of oceanic pelagic sharks and rays. Aquat Conserv., 18(5): 459-482.

Ebert, D.A., P.D. Coweley and L.J.V. Compagno. - 2002. First records of the longnose spiny dogfish Squalus blainville
(Squalidae) and the deep-water stingray Plesiobatis daviesi (Urolophidae) from South African waters. S. Afr. J. Mar. Sci., 24: 355-357.

Girard, M. and M. Du Buit. - 1999. Reproductive biology of two deep water sharks from the British Isles, Centroscymnus coelolepis and Centrophorus squamosus, (Chondrichthyes: Squalidae). J. Mar. Biol. Ass. U.K., 79: 923-931.

Guallart, J. and J.J. Vicent. - 2001. Changes in composition during embryo development of the gulper shark Centrophorus granulosus (Elasmobranchii, Centrophoridae): an assessment of maternal-embryonic nutritional relationship. Envir. Biol. Fish, 61: 135-150.

Hamlett, W. and T.J. Koob. - 1999. Female reproductive system In: Hamlett, W.C. (eds), Sharks, skates and rays. The biology of elasmobranch fishes, pp. 398-443, Baltimore, Maryland: The Johns Hopkins University Press.

Jones, T.S. and K.I. Ugland. - 2001. Reproduction of female spiny dogfish Squalus acanthias, in the Oslofjord. Fish. Bull., 99: 685-690

Jones, A.A., W.T. White and I.C. Potter. - 2005. An hermaphrodit Port Jackson shark, Heterodontus portusjacksoni, with complete and separate female and male reproductive tracts. J. Mar. Biol. Ass. U.K., 85: 1171-1172.

Kabasakal, H. - 2002. Stomach contents of the longnose spurdog Squalus blainvillei (Risso, 1826) from the North-Eastern Aegean Sea. Annales (Annals for Istran and Mediterranean Studies), Series historia naturalis, 12(2): 161-166.

King, M. - 1995. Fisheries Biology, Assessment and Management. Fishing New Books, London.

Koob, T.J. and I.P. Callard. - 1999. Reproductive endocrinology of female elasmobranchs: lessons from the little skate (Raja erinacea) and spiny dogfish (Squalus acanthias). J. Exp. Zool., 284: 557-574

Ledoux, J.C. - 1970. Affiniteés et origins du Squaus blainvillei de Mediterranée. J. Ichthyol., CIESM: 65-69.

Massutí, E. and J. Moranta. - 2003. Demersal assemblages and depth distribution of elasmobranchs from the continental shelf and slope off the Balearic Islands (western Mediterranean). ICES J. Mar. Sc., 60(4): 753-766.

Megalofonou, P. and A. Chatzispyrou. - 2006. Sexual maturity and feeding of the gulper shark, Centrophorus granulosus, from the eastern Mediterranean Sea. Cybium, 30(4): 67-74.

Ranzi, S. - 1932. Le Basi Fisio-morfologiche dello Sviluppo Embrionale dei Selaci, Parte I. Pubblicazione Stazione Zoologica, Naples.

Quignard, J.P. - 1971. Recherches sur la biologie de Squalus blainvillei (Risso, 1826). Trav. Lab. Biol. Halietique Univ. Rennes, 5: $125-141$.

Serena, F. - 2005. Field identification guide to the sharks and rays of the Mediterranean and Black Sea. FAO Species Identification Guide for Fishery Purposes. Rome, 97 pp.

Sion, L., G. D'Onghia, A. Matarrese and C. Mytilineou. - 2003. First data on distribution and biology of Squalus blainvillei (Risso, 1826) from the eastern Mediterranean Sea. J. Northwest Atl. Fish. Sc., 31: 210-219.

Spare, P. and S.C. Venema. - 1992. Introduction to tropical fish stock assessment. Part I. Manual. FAO Fisheries Technical Paper, 306, FAO, Rome.

Stehmann, M. - 1987. Quick and dirty tabulation of stomach contents and maturity stages for skates (Rajidae) squaloid and other ovoviviparous and viviparous species of sharks. Amer. Elasm. Soc. Newsl., 3: 5-9.

Tortonese, E. - 1956. Fauna d'ltalia. Vol. 2. Edizioni Calderini, Bologna, Italy, pp. 173-176.

Wourms, J.P. - 1977. Reproduction and development in Chondrichthyan fishes. Amer. Zoo., 17: 379-410.

Yano, K. - 1995. Squalidae. In: O. Okamura, K. Amaoka, M. Takeda, K. Yano, K. Okada and S. Chikuni (eds.), Fishes collected by the R/V Shinkai Maru around Greenland., 52p., Japan Marine Fishery Resources Research Center.

Zar, J.H. - 1996. Biostatistical analysis. Third edition. Prentice Hall, Upper Slade River, New Jersey, USA

Scient ed.: G. Pequeño.

Received April 13, 2010. Accepted September 8, 2010.

Published online March 8, 2011. 